\title{
PRESENT-DAY TENDENCIES IN THE MORPHO-SYNTAX OF ISTRÓ-ROMANIAN DIALECT
}

As compared to the idiom spoken by the southern Istro-Romanians who people several small villages and hamlets in the south of mount Učka, and speak a language subject to constant changes ${ }^{1}$, the idiom spoken by the inhabitants of Žejane (Yugoslavia) has preserved to a higher degree the archaic structures and elements inherited from proto-Romanian. The Istro-Romanians of Žejane have lived compactly to our days (102 house numbers, about 400 speakers) ${ }^{2}$, being more isolated from the massive influence, of Croatian (i.e., the literary variant of the Ceacavian dialect), and offering us, through their language, a pattern of Romance idiom (of the Romanian type) that has long opposed, especially phonologically and morpho-syntactically a powerful alloglotic influence (Croatian, Slovenian, Italian). The restrictive use of Istro-Romanian, especially in the last five decades (since it is hardly an instrument of communication, especially for the young commuters employed in the factories of Rieka, Opatia and the neighbourhood, or for those who, through mixed marriages, moved to other Yugoslavian towns of villages) is a process in full development even nowadays.

Though bilingual, both old and young Istro-Romanians have a well outlined linguistic awareness, being abe to prove in fact that to speak "a cuvintå po našu, po žejanski“ means something totally different from to speak "a cuvintå po hrvatski“.

The data offered by our investigations made in Žejane and Sušnjevica (in March, April and August, 1982), by which we checked, in the light of linguistic and

1 Sušnjevica, the place where most of the southern Istro-Romanian speakers live, is situated on an important road (Pazin-Paz-Labin), where, in the past, people used to speak Italian (Istro-Venetian) a lot, and now speak Croatian. On the other hand, in Žejane, which used to belong, in the past, to the Slovenian administration in Podgrad (Cittanova sul Carso) and to the Slovenian linguistic territory, having been geographically more isolated until the third decade of our century - and less subject to Italian influences, old Istro-Romanian elements have been better preserved.

2 The number of Istro-Romanians seems to differ from one author to another, in various statistics publiched along the years, oscillating between 525 (in 1850, Fr. Miklosich), 674 (in 1913, Schück), apud Sextil Pușcariu, in collaboration with M. Bartoli, A. Belulovici and A. Byhan, Studii istroromâne, II, București, 1926, p. 42-43; 450-500 (in 1959-1963); cf. August Kovačec, Descrierea istroromânei actuale, București, 1971, p. 23; and 500 (in 1964), cf. Radu Flora, Slovenačke leksičke posudjenice u istrorumunskom, "Linguistica" XII, Ljubljana, 1971, p. 68. We should notice that, while the number of the southern Istro-Romanians desreased rather rapidly according to the statistics we know (from 2428 in 1850, after Fr. Miklosich, to 800-1000 in 1959- 1963, after A. Kovačec), in Žejane, the number of the Istro-Romanians dit not decrease so dramatically in time. 
statistical base structures of the idiom spoken in Žejane, has confirmed that the pressure exerted today by the Croatian goes through all the levels of IstroRomanian, the morpho-syntactical one included. But this influence manifests itself in different ways, being reflected by numerous borrowings, and also by IstroRomanian innovations, following some Croatian pattern, and still remaining acquisitions of this idiom, as alloglotic elements, adopted to the Istro-Romanian linguistic system. By no means does this influence appear under the form of massive dislocations and disintegrations of whole compartiments of the system, through the replacement of the native linguistic structures by foreign ones, in some rare cases, though, this may happen, especially at the discoursive level of speech, when the bilingual Istro-Romanian, out of various reasons, occasionally passes unaweres from one code to another, alternating the linguistic structures ${ }^{3}$.

To illustrate the ease of the transition - in speach - from the Istro-Romanian code to the Croatian one and vice versa, we shall reproduce here two texts belonging to individuals of different generations:

“... Ke š-iča-n vârh de selište sus ... av ... ståra crkva, ståra bisęreka, betâra bisęreca ... e ši d-atunče pac a fakut. Nu štivu dupa kâta vręme av jos verit, oånč av čåoåta bisęreka facut, če-i ân Mune ... (Sanković Mate, aged 78, Žejane).“

One could see here the concurrence of the parallels in Croatian and IstroRomanian, the groded transition from the Croatian syntagm to the Istro-Romanian one, first of all through the substitution of the noum (crkva - bisereka), and then of the adjective (stara - betâra).

“... Am trei fečor': doj muški ši o ženska, doi fil' ši-o fil'e. Doi âs ânsuråc'. Såv ânsuråt. Ur åre fil', ur fil'. E ânke-i fil'a de meritåt (Dorićić Anton, Lu Kljone, aged 55, Žejane).“

Both our collocutors (but not only they) expressed their desire to be recorded while speaking properly "po žejanski" and, therefore persisted in trying to remember the "forgotten" equivalents in their idiom.

The "mixed" character of Istro-Romanian and the bilingualism of the IstroRomanians have drawn the attention of well-known Romanian and foreign linguists

3 Thus, some of the informers reproduce "perfectly" older texts, well-fixed in time - poems, songs, proverbs and sayings - or speak with ease about their family and their daily work. But when they are requested to take part in a dialogue, built ad-hoc on different subjects (especially, social administrative ones), there occur, in their speech, numerous switches from the Istro-Romanian register to the Croatian one, with which they are equally familiar, so that it is difficult to establich, each time, from the beginning, whether these switches are accidental or whether we are dealing with hybrid elements and structures of the contemporary Istro-Romanian system, resulting from an interlinguistic mixture. 
since the 19th century ${ }^{4}$. Several reasons have been given either to support the theory according to which the dialect under discussion is gradually losing its consistency until it disappears together with its last speakers ${ }^{5}$, or to support the theory regarding the rapid disintegration of Istro-Romanian, through the process of mixing, under the prssure of the contact languages, with cultural and economic (and administrative) prestige, lately under the pressure of Croatian", "the second mother langue of the Istro-Romanians“, as A. Kovačec remarks (A. Kovačec is the author of the latest monograph of contemporary Istro-Romanian in Žejane).

Despite the multisecular pressure exerted upon this idiom by Croatian, Slovenian and Italian (Istrian Venetian), Istro-Romanian is actively used only in Žejane (3 kilometers away, in Mune, it has not been spoken for a long time); it is used by the villagers, in the family, in the street, in differrent everyday or solemn circumstances, on the occasion of traditional folk holidays (e.g., the custom of the masks - "Pust" -, when they go to Opatija), etc. Thus, we cannot say that contemporary Istro-Romanian has an exclusively "familial" status (because it does not!). On the contrary, in Žejane, Istro-Romanian is the language of the village, as A. Kovačec states, in the quoted work (p. 195).

Considering the specific character of this dialect, its resistance to foreign ingluences, also noticed by E. Petrovici and P. Neiescu, ${ }^{7}$ we thought it useful to see if all the borrowings from Croatian penetrate the dialect equally easily and have the same degree of functionality, if all the new acquisitions leave their stamp upon the structure of the idiom to an equal degree, determining its future evolution.

Like any other idiom functioning in an unrelated linguistic medium, the system of Istro-Romanian presents both areas, more resistent to the alloglotic influence, in wich the elements of the so-called "prestige" languages penetrate with more difficulty, and in which the persistency of the Istro-Romanian elements is greater (the phonological, morphological and morpho-syntactical systems), and areas in which the alloglotic elements literally invade entire compartments (the vocabulary, but also the sentence word-order suprasegmental elements).

The persistency of the old Latin elements in Istro-Romanian at the phonological level, fully and repeatedly exemplified, is proved again in more recent investigations ${ }^{8}$. The specific phonetic features of this idiom, revealed by Sextil

4 See in this respect S. Puscariu, Studii istroromâne, III; Bucuresti, 1929. References to the latest works about Istro-Romanian see in Petru Neiescu, Din fonologia dialectului istroromân, in "Studii și Cervetari Lingvistice“"XXXI (1980), nr. 2, p. 137-148.

5 Cf. E. Petrovici, Rezistenta sistemului fonologic la o puternică influență străina, "Cercetări de Lingvistică“ IX (1964), nr.l, p. 35-39; see also A. Kovačec, op. cit., p.34.

6 I. Coteanu, Cum dispare o limbă (istroromâna), București, 1957.

7 Cf. E. Petrovici, P. Neiescu, Persistența insulelor lingvistice, "Cercetări de Lingvistică“ IX (1964), nr. 2, p. $187-214$.

8 P. Neiescu, Din fonologia dialectului istroromân: see note 4. 
Puşcariu in his "Studii..."9, by his predecessors and followers, are still thoroughly fixed in the speech of the majority of Žejane inhabitants, inquired by us. More or less important modifications can be observed especially in the field of syntactic phonetics.

We concentrated on older or more recent morpho-syntactical processes, on the concurrence, in the speech of our collocutors, of structures belonging to the Slavic and the Romanian types, on their frequency in recorded texts of different lengths, on the functionality of the Istro-Romanian morpho-syntactical structures in various situational contexts. In connection with this comportament of contemporary IstroRomanian; we notice especially the well-preserved forms in the paradigm of the noun, of the pronoun and of the verb.

What we should mention in connection with the evolution of the idiom is the deep tendency, especially of the young people, to modify their articulatory basis under the influence of the Ceacavian Croatian dialect, which had important effects on the proper reception of the messages by the research worker, although he masters Romanian and Serbo-Croatian, and is acquainted with Istro-Romanian as well. The (special) articulation of some sounds, especially of some groups of consonants at the boundary of two distinct lexical units, makes many utterances difficult to understand. Because of this, mutations appear on the level of syntactic phonetics, with consequences easy to foresee in the evolution of the idiom, which will have to form the object of several future, complex investigations.

From amoung the morpho-syntactical elements of the idiom that contribute to the persistency of Istro-Romanian, to its preservation as a "linguistic island" in a medium strongly influenced by Croatian, we notice first of all, the well - preserved forms in the paradigm of the noun, the pronuon and the verb.

The analytical forms of the nouns marked in the Genetive-Dative by $l u$ (masc.) and le (fem.), e.g., lu bovu, le mul'åre are widely spread. Synthetic forms can be found only in poetry, sayings and proverbs, where these forms became fixed long ago ${ }^{10}$. E.g.,

Oi l'epure nu žukå / Ke te båte måia ta/

$\mathrm{Ku}$ spinušu pluguluj / Preste buka curului.

(Sanković Mila, Lu Tonić, aged 47, Žejane)

One could observe the good preservation of the possesive and demonstrative adjectives and pronuons, of old forms inherited from proto-Romanian, which had a specific evolution in Istro-Romanian, but which became stable depending on person, number of possessors and possessed objects, case, gender, exactly like in

9 See note 2 .

10 Op. cil., p. $20-25$. 
Dacian-Romanian. At the same time, ane could note the generalization of the forms without emphatic $a$ (čela). For example, here is a text about photos:

“C̆åsta-i fil'a lu fråtele. Česta. Â česta-j fil'u a lui, pak li s-av učis. Siromåku, de-osemnainst let. Ku avtu-av mlatit ân ståblo ši učis s-av. Â deco! De osemnainst let li s-av učis. Ia Ku avto. Časta-i ča lu a mel've fråte fil'u. Česta-i fil'u a lui. Česta-i unukulu lu a lui. Česta-i spomeniku a mel've fil' če ie-n Australie murit. Ačåsta-i Eda. Biserka lu Draghe când s-å meritåt ... Časta-i casa čel've če-i cu cålu ...)

(Sanković Katarina, aged 81 , Žejane)

Other constructions that are frequently met are those with the personal pronoun in the Dative; they underline the idea of appurtenance in contexts about family members, friends, as in the following text about the family photos in the photo album:

“Česta mi-e Sergio. Časta mi-e amerikånka ši fråtele meu mai betar če-i ân Trst. Čåsta-i Ilco, sev fil'u, mev nepot ši uịcu... Čåsta mi-e sora ši omu ... İo ši Robert, le Biserke fil'u, ina, uxunuku. C̆åsta mi-e le sora din Toronto fil'u ..." (Turkoviš Draga, aged 56, Žejane).

As far as the Istro-Romanian verb is concerned, we can notice that the old inflection is well-preserved, generally, but that among the tenses of the indicative, the most frequently used are the present, the future and the perfect. The forms of the restrictive conditional occur both in the speech of the adults and in that of the younger generation:

“...Ke in-a zis ke va fåče karle čela profesor čå knige d-este trei selišt. Kum s-o popalit cân a fost â čå oste ši čả. Ali nå-v ânka i্র kumparå. Io baš ręš vedę kum s-ar pise ..."

(Senković Mate, aged 78, Žejane).

"Reš ino ân četåte ramâre, ma n-åm kole mes."

(Turković Sergio, aged 27, Žejane).

The conjunctive has forms identical with the indicative (only the verb a fi ("to be“) - has distinct forms for the conjunctive, but even these forms are frequently replaced by indicative ones), following, in use, the Croatian pattern with the conjunction neka (more rarely - se):

"Kui i i-e fome, neka-ntreba" (Sanković Maria, aged 50, Žejane).

Even nowadays, the forms of the conjunctive with neka occur in parallel with infinitive constructions, which, being old, are thoroughly fixed in Istro-Romanian: 
"Š-atunč a verit spure“ (Sanković Drago - Brko, aged 38, Žejane).

"Veric merindå!" (Sanković Maria, aged 50, Žejane).

“Akmo morem noi doin be!" (idem.).

"Ši tudi pac s-a mes ašteptå la niva de fažou ši de cumpir. Pac s-a moreịt ašteptå " (Sanković Mate, aged 78, Žejane).

"Fil'i meg ân četåte živi:“ (Diričić Jelka, aged 66, Žejane).

"Ši moreint-åm mere ân soldatie..."; “...ke ćåce se koće la ur mesic nu-ỉ dost za živi ši mire piaźe pemintu lucrå ke cire ân pemint lukra si vera ịe âi sâr..." (Belulović Frane, aged 61, Sušnjevica).

From among the elements that persist the morpho-syntactical system, having a high frequency, both in dialogues and in monologues, one can notice the contracted structures with indefinite pronominal or adverbial value; they are, in fact, predicative, lexicalized formations, of the type: nuškårle "somebody“, $(n u+\check{s} t i v u+k a ̊ r l e)$, nuščire (=nu + štivu + čire) "somebody"; nuškum, nuškât, nuškând ...; maimoaint'e $z i$ "the day befor yesterday" (the synthesis of the syntagm mai moant'e $z i$ "the previus day").

Also well-preserved are the constructions with cardinal numerals from 1 to 6 , and those with ordinal numerals of Romance origin. Even the numerals from 7 to 19 , the tens and the hundreds, which are lexical borrowings from Croatian (unlike in Dancian-Romanian, where they are Romanian formations), are used in speech, following the old Romanian pattern; for example:

"Mul'åra lukra-n šula påtru ure na dan. Ie moreit lukrå sto osemdeset ši do ure ... Io voi avę u decembru šestnajstog petdeset ši činč. Exa åre akmo dvajset let..." (Doričić Anton, aged 55, Žejane).

To illustrate the persistency of the archaic elements and of the innovations which do not occur under alloglotic influence, but as a result of internal factors, we shall give, in what follows, two texts in which the old Latin elements and the structures of the Romanian type are preponderant:

“Pure, pure-n fok ke se va stinže. češt'a toc šedu ocol' de špurghet, ma nu va ničur ânutru pure. D-atunče cuvintu ke l'-e råče. Nu prenča pure de sus. Ašå. De jos nu, ma de sus.“ (Sanković Drago - Brko).

“Uri rumuń verit oånča fir ku cål’i. Pac au užejt ziče: Bura domaręåca! Ši Bura sera! Ânka d-atunče štiu, jo am vezt, more-i deset let. Pak štiu ši pak am ântrebavejit kum č-av zis. De "šterne" av zis fântâna. Noi šternea zičem. Fântâra k'emåm kolę afåra. Betâri au zis fântâra. Čel'i č-akåsa skopes ka ši la uša - čeå-i šternea. E ča če-i afåra fakuta din selište, č-åv betâri fakut, ča se kiåma fântâra po našu“ (Sanković Mate). 
On the other hand, as we have already pointed out, Istro-Romanian changes its aspect in the compartments less resistent to the alloglotic pressure. The areas subject to the massive Croatian influence have gradually lost their consistency, their specific character; certain subsystems or structures of the idiom have developed under the influence of a foreign pattern (e.g., aspectual oppositions, predicative constructions with neuter adjectives and with adverbs in $-o$, the numerals from 11 to 19 , the adverb, the word order with its multiple morphological implications, such as the dropping of the articulated forms of preposed adjectives, the dislocation of the auxiliary from the verb, elliptical constructions, etc.).

The vocabulary, especially, is subject to changes, and this has direct effects on morpho-syntax, because, after all, it is borrowings that explain the morphosyntactical structures of the mixed type.

Thus, as I. Coteanu ${ }^{10}$ says, in the Istro-Romanian basic word stock, from the point of view of their origin, over 30-35 per cent of the terms are Croatian or Slovenian; the figure R. Flora ${ }^{11}$ gives, on the basis of a study made on a shorter text is 50 per cent. A. Kovačec, on the basis of his statistical glossary of 85,000 IstroRomanian words, considers that Latin terms belong to the basic word stock, and Slavic (Croatian) words belong to the rest of the vocabulary; he states that Slavic verbs are almost three times more numerous than Romance verbs, but, in contexts, the situation is reversed: Slavic verbs have a lower frequency, as compared to the old Romanian verbs ${ }^{12}$.

As a result of the Istro-Romanians pluri-linguism, in morpho-syntax innovations are more numerous than the archaisms. Thus, having taken over the Croatian aspectual oppositions, the verb, which is the part of speech with the greatest functional yield in a complex sentence, has both hybrid structures with Istro-Romanian functional root and indicator (suffix) and with Croatian aspectual indicator (prefix) $)^{13}$, as well as complete Slavic structures, in which only the infinitive indicator is of the Romanian type ${ }^{14}$ : Cf. legå - razlegå, plânže - zaplânže, durmi - zadurmi, učide - zaučide, furå - pofurå, etc., respectively, kopęi - skopęi, reži obreži, leti - doleti, etc. ${ }^{15}$

The transfer of Slavic aspectual indicators, together with their functions, in Istro-Romanian shows the ease with which present-day speakers can switch from

11 Op. cit., p. 72.

12 Op. cit., p. 202.

14 Cf. similar situations in the Banat subdialect: intoarce-prolintoarce, veni - proveri, turna - doturna, prostî - doprostî, etc.

14 Like in the Romanian idiom spoken in the valley of the river Timok, in the Negotin area: prekini, prozavi, pakui, razumeni, počni (io nu počnesc).

15 Cf. T.P. Klepnikova, Funkcii slavjanskich glagol'nych pristavok v istrorumynskom, in "Voprosy slavjanskogo jazykoznanija“", vyp. 4, Moskva, 1959, p. 34-72. 
one language to the other, the general and active character of the bilingualism of Istro-Romanians ${ }^{16}$.

As far as the two directions followed by the Istro-Romanian verb are concerned (in the marking of predicativity with aspectual forms), we can notice a tendency to avoid the hybrid suppletive opposition and to fully accept the Croatian aspectual opposition (especially, in the speech of the young people, who use, e.g., cr. predi spredi instead of istr.-r. torče - potorč ${ }^{17}$, like in the idiom spoken in the Timok area). There are well preserved hybrid forms in which the Croatian word that should have reeplaced the Romanian one, has a more reduced phonetical body ${ }^{18}$. In the absence of formations like * $p i$, *ori, we meet well-fixed suppletive oppositions, of the following type be - popi, ara - zori.

The cases in which the aspectual opposition is not expressed morphematically, it being understood only contextually, are also frequent: vegl'å, akacå, spure, tråže, ziče, muri, avzi, etc.

Another area deeply influenced by the Croatian language is word order. Word order in Croatian is relatively fixed, because syntactical functions are generally expressed morphematically, and Istro-Romanians often use this free word order even where the syntactical functions should be expressed by word order. One of the effects of this free word order is the dislocation of the auxiliary from the verb (cf. cr. sam ga/jo videla), e.g.:

Kum åm ino kuvintåt, åv ši ie, Leka Moråriu ši mul’åra. “ (Sanković Anton, aged 82, Žejane)

"Ân kârka ku brenta am åpa purtåt. Ku kârkoåta." (Senković Mila, aged 47, Žejane)

"Mâre voị jio učide ...uåstaz am vo učis. İo-l akmo učide..." (Sanković Drago - Bârko). "...Kând åm de mic fost ..." (idem.)

"Nu štivu dupa kâta vreme av jos verit" (Sanković Mate, aged 78, Žejane)

"Pak s-åv ku traktoru učis." (Sanković Katarina, aged 81, Žejane)

It is true that we should not always look for the cause of these deviations from word order exslusively in the imitation of the Croatian pattern of speech, but - as A. Kovačec ${ }^{19}$ points out - also in the need of the Istro-Romanians to express syntactical relations morphologically and to achieve a logical rather than grammatical connection between the parts of the sentence.

16 About the bilingualism of the Istre-Romanians, see A. Kovačec, op. cit., p. 124. See, also, R. Flora, Citeva observatii cu privire la bilingvismul manifestat în graiurile istroromânilor, in "Actele celui deal XII-lea Congres internațional de lingistică şi filologie romanică“, II, București, 1971, p. $1009-1022$.

17 Cf. A. Kovačec, op. cit., p. 127.

18 Idem, ibidem.

19 Op. cit., p. 178. 
One should also mention the frequent use of elliptical forms by IstroRomanians and by Croatians, e.g.: "Kum am jao kuvintåt, åv ši l̆e“; "Deset åm ši više (åm durmit ši više vręme)“.

The use of the neuter forms of adjectives and adverbs, following the Croatian pattern in - $o$ in predicative constructions is generalized: Iako buro!, but, also, more rarely: Bur a fost! (Sanković Maria)

Cf. also: Če-i de novo? Âj tåmno. Âi fino. Ke lor l'-e čå fino... İe opasno, pote omu muri. Fina fętina, e lungyo se porta (M. Sanković)

More rarely, in the older people's speech one comes across forms like: Âj bire. Â, ča nu-i bire. (M. Sanković). Cf. rom. E bine. Nu-i bine.

Another field in which Croatian forms have imposed themselves is the Vocative, especially in the case of borrowings: Kume! Sinko! (but, as well as with other words, like: Fetice!).

"Fęto, fęto, fętice, /Namažec to ušice!/

Ke-c vå veri froåỉeru /Rožice la drọakuluị! “ (Maria and Draga Turković Žejane).

Cf. also: "Ce tu plânzi musatę fętę?" (Belulović Frane, Frane lu Fabro, Sušnjevica, aged 61).

Concluding, we must say that the pressure exerted by a linguistic system upon another, with which it is in contact, manifests itself more or less intensely, depending on the resistent or fragile character of the areas where the pressure is exerted, (a) either as a transfer of entire structures and elements, in their original form, unadapted to the system of the contact language;

(b) or as a transfer of partial structures and elements.

In this latter case, we may distinguish, between different types of linguistic translation loans (full and half), and hybrid morphological and morpho-syntactical structures, which, in turn, may be of two types, depending on the direction in which the intersystemic pressure takes place and on the character of the systemic forms which impose themselves in present-day innovations, depending on the pattern (internal or external) followed by these hybrid constructions.

Undoubtedly, all hybrid structures are an expression of the instability of some subsystems, belonging to idioms placed in a medium of powerful outside influence. But not all hybrid structures reflect, to the same extent, the state which foretells the further evolution of that idiom, in its various compartments, others are preserved unchanged for a long time, being frequently used by the speakers. Thus, they certify the importancw of the areas in which they occur, the stability and solidity of the respective subsystems, and - finally - the resistence of the idiom to outside influen- 
ces, the preservation of its identity through "active resistence" to massive dislocations and maintenance of its specific peculiarities to the disappearance of its last speakers. The latter facts anticipate, in some way or other, the future of the idiom which is subject to the pressure of one foreign language, sometimes the influence of three languages, as is the case with Istro-Romanian. The preservation - in time of this type of structures - for example - is eloquent from this point of view, as well as the relatively small difference between the Istro-Romanian morphosyntactical structures present in the texts recorded more than 130 years ago, aud published by Pietro Kandler in the magazine "Istria" starting with 1846, and those contained in the texts recently recorded ${ }^{20}$.

In other words, we would like to state that, in order to see the directions in the evolution of contemporary Istro-Romanian, it is necessary that, besides the interpretation of borrowings and of various types of linguistic translation loans, one should establish, on the basis of materials offered by more recent investigations: (a) the domains of the idiom and the modelities in which its persistent and its nonpersistent features manifest themselves; (b) the degree of vitality of the hybrid morphological and morpho-syntactical structures.

Starting from these theoretical considerations, admitted as a premise in the processing stage of recorded data, we have come to the conclusion that, in contemporary Istro-Romanian, the following types of morpho-syntactical structures are obvious in the current speech Istro-Romanians:

I a) Non-hybrid elements or structures of the Slavic type (Croatian, Slovenian) that function as autonomous units in a medium of the Romanian type, for example:

- constructions with pronoun saki "each", "anybody", nešto "something", tako nešto and with adverbs (iako "very"; po romunski, po željanski, skupa - pojedinačko, čuda - o mârva, više nikad, gotovo je), with prepositions (po, za, etc.) and conjunctions (neka, nego, ali, etc.);

- constructions with adjectives, especially in predicative constructions (neki je razlika; jako-i bolan; je nepokretna, nego bolna jako; but also upala pl'ut'a "pneumonia", čuda - o mârva vrẹme "a long time - a short time");

- constructions with numerals from eight upwards (akmo nazad dvajset let);

- constructions with adverbial nominal modifiers (za vrexme rata);

20 See our work Texte istoromâne si glosar (Cu un słudiu introductiv "Istroromâna - azi“), Timișoara, 1987, Tipografia Universitații din Timișoara. 
- adversative - comparative constructions (ne samo jo, nego više l'udi) ${ }^{21}$;

- phrases with the Vocative (Ai l'udi, Isuse!; Kume!) etc.

I b) Autonomous morpho-syntactical structures of the Romanian type (including the Slavic elements in the older strata, also existent in Daco-Romanian); (see the examples above).

\section{Hybrid morpho-syntactical structures of type $\mathbf{A}$ and $\mathbf{B}^{22}$ :}

II. A) Morpho-syntactical structures of type A are stable and resistant IstroRomanian structures, in which the Slavic element is adapted, subordinated to the Istro-Romanian system and always functions depending on a certain structure or an Istro-Romanian micro-context, in one and the same unimportant position.

In this case we distinguish two situations, depending on the structure of these formations or contructions:

(1) Firstly, there are the cases in which the lexematic theme is Slavic (Croatian, Slovenian), while the grammatical formant (the inflexion, the article) is of the Romanian type; e.g., the inflexion of the verbs of Slavic origin (jo obečes, tu obečes, ile obeče, noi obečim, voi obečic, iel' obečes "to promise"), the situation is the same in the case of the Romanian verbs of Slavic origin in the Dacian-Romanian (eu sădesc, tu sădești, el sădește ...), spoken today in Romania or in other areas, for example, in Yugoslavia (in Negotin - Timok area: io pakuiesc, to pakuiešc ..."to pack"; io razumenesc, tu razumenešc, noi razumenim "to understand"; s-o prekinit veza "the connection wascut"; mă sikiresc "I'll get angry"; ne-am prizăvit "we announced ourselves", following the general pattern, productive on the Romanian territory, in which the flexion forming elements play the main role.

21 Although they have the word omir "people", the speakers prefer sl. l'udi, it being more convenient for them to incorporate, in this Croatian phrase, a Slavic constituent of the construciton is manifest. This phenomenon of induction of the terms with the same origin, within more developed syntagms appears frequently in the speech of Istro-Romanians, being fully justified from a psycholinguistic point of view. Thus, when the Croatian autonomous constructions have a wider frequency in a text, we think that we are not dealing with a case of interlinguistic mixture at the syntactical level, but rather with a conscious or unconscious abandonment of the idiom in favour of the of ficial language, out of different reasons (e.g., the spreakers' intention to be better understood by the research worker, their mood in certain situations, etc.).

22 The terminology used in this study on the Typology of morpho-syntactical structures, has a conventional character. It is used out of methodological reasons, and it helped us to formulate several pertinent findings about the recorded texts, concerning the functionality of some formations and syntactical constructions in which the Slavic element is obvious and productive, but which, esentially, remain older or more recent innovations of Istro-Romanian, unlike the constructions which the speakers use accidentally while being inquired, when, in order to be more persuasive, they shift from one code to the other. 
Another example of such hybrid structures with a greater degree of vitality in the Istro-Romanian system is the articulation of the nouns and adjectives with the definite article (siromåku, selištea, ženskile, muškile, volitvele, såkile, divile, svetile, srednile, drobnile /kumpir/, ununuku, etc.).

(2) Secondly, there are frequent situations in which, at the level of compound sentences, the building material is Slavic, but the modality in which it functions in a context, its use in the speech of Istro-Romanians is imposed by their linguistic system. For example:

"Oko de sedamdeset let va ave ie; Stopedeset metri - zråc̆na linija; pol de ure; vârhu de seliüte. Če stec? Oånč živic? Obečes, pak nu plates. Såkile-l pote zaučide. Akmo-s volitvele. " " $\mathrm{He}$ ' she'll be 70 . One hundred and 50 meters - in a straight line; half an hour; the peak of the village; Who are you? Are you living here?; I promise, but I won't pay. Anybody could kill it. The elections are taking place now").

II. B) Hybrid structures of type $B$ are Istro-Romanian structures with a low degree of resistence, in which the Slavic element plays an important part, although it does not function as a Slavic autonomous element (like in type $I a$ ) in a context. Even if it partially adapts itself to the Istro-Romanian system, the Slavic element exerts an active pressure upon it, making the Istro-Romanian linguistic units function following the respective Slavic patterns. There are two situations in this case as well:

(1) When the root (sometimes the lexematic theme) is Istro-Romanian, but the grammatical forming elements are Slavic: cf. the aspectual prefixation system (torče - potorče, legå - razlegå, latrå - zalatrå, učide - zaučide, mânkå - namânkå, durmi - zadurmi, etc.); neuter adjectives in $-o$, used to render predicativity ( $\hat{A} i f f i$ no; ậ tamno; ậ buro), vocative forms (Fęto, fęto, fętice!; Sinko!).

(2) When the building material is Istro-Romanian, but the modalities in which it functions in the sentence are Slavic (the use of neuter forms of the adjectives to mark predicativity; of ellipsis, of free word order, i.e., the dislocation of the auxiliary from the verb, of some case forms, of some constructions with multiple parts, after the Croatian pattern, etc.) For example, Više če- $i$ måi buro (cf. istr.r. bur) Ča nu-i fino. Če-i de novo? (cf. istr.r. nou);

Ân Dunai a lu Franc Iozef åm fost. $\AA m, \AA m$.

A ma la voi de moånt'e fost. Oånče $n-u \dot{a}$.

Io-l voi akmo učide. N-åv ânka iešit. Ám åpa purtåt. Vândut-åm-vo.

... bilo familie, bilo družstvo, bilo če ...;

... bilo de pena, bilo de če ...

Here are some general conclusions on the evolution of contemporary IstroRomanian, in its main compartments: 
1. Hybrid constructions $(I I B)$ seem to be well-fixed, as a result of the resistance to foreign influences of the dialect, in those areas where the speakers did not accept global borrowings, but only the foreign pattern. In such construction, the borrowing of the foreign elements was made gradually, in its more stable compartments Istro-Romanian, has subordinated its acquisitions from Croatian or Slovenian to its own morpho-syntactical system, has restructured them in it.

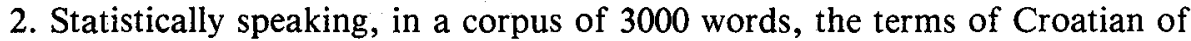
Slovenian origin, are almost $1 / 3$ out of the total vocabulary, and the words of Latin origin represent $2 / 3$. Out of the total of 325 complex and compound sentences in the recorded text, the autonomous morpho-syntactical structures of the Slavic type ( $I$ a $)$ represent 9.5 per cent, those of the Romanian type $(I \mathrm{~b})$ represent 27.5 per cent and the hybrid structures $(I I A)$ represent 38 per cent, as compared to type $I I B$, where they represent only 25 per cent.

The ratio between the different types of morpho-syntactic structures differs, in smaller parts of the text, depending on the thematic field tackled. The number of structures belonging to type $I a$ and of the hybrid structures of type $I I B$ increases in the texts dealing with the activities of various administrative and social institutions having Croatian legislation.

3. The following functional aspects are significant for the evaluation of evolutive directions of contemporary Istro-Romanian:

- the relatively frequent use of the autonomous Croatian constructions and of the hybrid constructions of type $I I B$ (especially by the young people and less so by the adults), in texts where the social administrative aspects are central, and the less frequent use of these structures in texts about the life of the village and the everyday activities of the Istro-Romanians;

- the preservation (with a high frequency) of the Istro-Romanian autonomous morpho-syntactic structures of type $I b$ and of the hybrid structures of type $I I$ $A$, which means that Istro-Romanian will not disintegrate rapidly under the pressure of the Croatian system, but will keep being used actively as a local idiom, as long as its speakers live.

4. The partial taking over of foreign elements in hybrid structures (e.g., in aspectual oppositions) has been done gradually. Unlike the structures of type II $B$, type $I I A$ structures reflect the degree of resistance of the Istro-Romanian grammatical system, the fact that the Istro-Romanian elements impose their Romance character upon the hybrid structures, ordering the Slavic material a manner that has been preserved over the centuries.

The full taking over of some Slavic constructions, a phonomenon often encountuend in the speech of the Istro-Romanians (of Žejane and Sušnjevica inhabi- 
tants), is not a weakness of the system of their dialect, but rather their acceptance, as bilingual speakers, of global borrowings, in their original form, out of socialadministrative reasons. The weakness of the system, in the areas that are more susceptible of linguistic disintegration, is illustrated especially by the hybrid structures of type $I I B$, in which the limited degree of vitality of the old Istro-Romanian element is evident.

5. Interpreting the entire recorded material, in its most essential points, and reducing the facts of language to types, we come to the final conclusion that the linguistic pressure exerted on contemporary Istro-Romanian affects its morphosyntactical system, first of all, through the mutations which it produces in the vocabulary and to the extent to which these lexical modifications become absolutely necessary to the respective linguistic community, in its various spheres of communication.

Resumat

\section{TENDINTE ACTUALE ÎN MORFOSINTAXA DIALECTULUI ISTROROMÂN}

În lucrare se încearca o prezentare sistematică a modului în care se produce astăzi concurența structurilor morfosintactice de tip slav (croat/sloven) și a celor de tip românesc. Se remarcă frecvența acestor structuri în texte de diferite marimi şi functionalitatea lor în diverse conexte de situație.

Se disting, în acest sens, patru tipuri principale de structuri morfosintactice, curent utilizate de vorbitorii istroromâni, în care ponderea și stabilitatea o are fie (1) elementul de tip slav adaptat (a) integral sau (b) partial sistemului lingvistic istroromân, fie (2) elementul de tip românesc cu ofuncționalitate (a) autonomă în plan sintagmatic sau (b) dependentă de modelul slav.

Rezistenta idiomului la presiunea aloglotă masivă se reflectă tocmai în combinațiile lexico-sintactice mixte, care ilustrează tendința de păstrare a identității istroromânei prin 'împotrivire activă' la dislocări masive de ordin sistemic și menținerea particularităților sale specifice pîna la dispariția ultimilor vorbitori.

Elocvent în acest sens este rezultatul analizei unui eşantion de 325 de fraze dintr-un text înregistrat: sintagmele constituite prin alăturarea elementelor de tip romanic şi a celor de tip slav reprezinta $38 \%$ din totalul construcțiilor delimitate, cele constituite exclusiv din termeni vechi românești $-27 \%$, iar cele formate numai din termeni slav $-9,5 \%$, restul de $25 \%$ fïind constructii sintactice, în care elementele constitutive vechi românești sînt structurate morfosintactic dupa model slav (croat/sloven). 